\title{
Are anthropogenic factors affecting nesting habitat of sea turtles? The case of Kanzul beach, Riviera Maya-Tulum (Mexico)
}

\author{
Aurora Oliver de la Esperanza ${ }^{1}$ Alejandro Arenas Martínez ${ }^{2} \cdot$ Miriam Tzeek Tuz $^{2}$. \\ Ernesto Pérez-Collazos ${ }^{1}$
}

Received: 29 January 2016/Revised: 17 November 2016 /Accepted: 17 November 2016

\begin{abstract}
Marine coast modification and human pressure affects many species, including sea turtles. In order to study nine anthropogenic impacts that might affect nesting selection of females, incubation and hatching survival of loggerhead (Caretta caretta) and green turtle (Chelonia mydas), building structures were identified along a $5.2 \mathrm{~km}$ beach in Kanzul (Mexico). A high number of hotels and houses $(88 ; 818$ rooms), with an average density of 16.6 buildings per kilometer were found. These buildings form a barrier which prevents reaching the beach from inland, resulting in habitat fragmentation. Main pressures were detected during nesting selection (14.19\% of turtle nesting attempts interrupted), and low impact were found during incubation $(0.77 \%)$ and hatching (4.7\%). There were three impacts defined as high: beach furniture that blocks out the movement of hatchlings or females, direct pressure by tourists, and artificial beachfront lighting that can potentially mislead hatchlings or females. High impacted areas showed lowest values in nesting selection and hatching success. Based on our results, we suggest management strategies to need to be implemented to reduce human pressure and to avoid nesting habitat loss of loggerhead and green turtle in Kanzul, Mexico.
\end{abstract}

Electronic supplementary material The online version of this article (doi:10.1007/s11852-016-0473-5) contains supplementary material, which is available to authorized users.

Ernesto Pérez-Collazos

ernextop@unizar.es

1 Departamento de Ciencias Agrarias y del Medio Natural. Escuela Politécnica Superior de Huesca, Universidad de Zaragoza, Carretera de Cuarte s/n, 22071 Huesca, Spain

2 Flora, Fauna y Cultura de México. A. C, Playa del Carmen, Mexico
Keywords Beach management - Caretta caretta . Chelonia mydas $\cdot$ Eco-touristic certificate $\cdot$ Green turtle $\cdot$ Hatching success $\cdot$ Loggerhead $\cdot$ Nesting selection

\section{Introduction}

During the last two centuries, human activity has resulted in habitat loss, overfishing, introduction of invasive species, and contamination of natural habitats. All these actions have caused a massive biodiversity decline (Scherer-Lorenzen and Coomes 2014; Arellano-Peralta and Medrano-Gonzalez 2015; Costello 2015). Sea turtle species are facing numerous conservation challenges worldwide (Jackson et al. 2001; Chaloupka and Limpus 2005; Hamann et al. 2010). Nesting habitats are severely threatened by global climate change and by anthropogenic effects (Schlacher et al. 2007), such as, egg harvesting (Kamezaki and Matsui 1997), egg predation by domestic animals (Chaloupka 2003), turtle hunting (Gardner and Nichols 2001), habitat degradation by coastal building development (Kamezaki et al. 2003), direct tourist pressure (Frazier 2000) and marine captures in coastal and pelagic fisheries (Poiner and Harris 1996; Julian and Beeson 1998; Chaloupka et al. 2004; Peckham et al. 2007). Interactions of these threats are causing a dramatic worldwide reduction of sea turtle populations (Wyneken et al. 1988; Scherer-Lorenzen and Coomes 2014).

Mexico coasts host a high number of species and diversity (Bolongaro et al. 2010). These coasts are also suitable for reproduction, shelter and breeding of many marine species (Bolongaro et al. 2010; Arellano-Peralta and MedranoGonzalez 2015). Six of the seven species of sea turtles in the world can be found in Mexico coasts (UICN 2014): the green turtle (Chelonia mydas), the loggerhead (Caretta caretta), the olive ridley sea turtle (Lepidochelys olivacea), Kemp's ridley 
sea turtle (Lepidochelys kempii), the hawksbill sea turtle (Eretmochelys imbricata) and the leatherback (Dermochelys coriacea). Nevertheless, over the last 40 years, several touristic infrastructures have been built in several coastal regions, especially in the Caribbean North East Mexico. Although this growth has contributed to the economic development of the country, particularly in Cancún and the Riviera Maya areas, there have been significant impacts that have resulted from this growth, including loss of important natural habitats and an increasing tourism pressure that affects many coastal species, especially those that nest in beaches (Arellano-Peralta and Medrano-Gonzalez 2015). Among these threats, is light pollution which is an important anthropogenic pressure that can reduce the reproductive success of sea turtles (Verheijen 1985; Witherington et al. 1990), could modify hatchling behavior, and probably also affects female nest site selection (Witherington et al. 1990; Kamrowski et al. 2012). The implementation of massive tourism and infrastructure (hotels, cabins and beach furniture) might alter sea turtle nesting, causing nesting abandonment as a direct consequence of the proximity of human presence (Witherington and Martin 1996). Therefore, conservation actions must be conducted to diminish these threats. Several decades ago, egg poaching had claimed nearly $100 \%$ of all eggs laid on the Mexico Pacific and Caribbean coasts (Sarti et al. 2007). However, today this threat has decreased $(<15 \%)$ as a result of the combination of beach patrollers, wildlife refuge conservation policies and educational programs, which changed attitudes of local communities (Chacón-Chaverri and Eckert 2007; Tomillo et al. 2008).

This study documents the nesting habitat degradation by tourism pressure of loggerhead and green turtle in Kanzul Beach, located in the "eco-hotel" area of Tulum, Quintana Roo, in southeastern Mexico, in the Caribbean coast (Fig. 1). The coast of Quintana Roo is one of the most important nesting sites for the green and loggerhead turtle (Zurita 2009) but it is also subject to an increasing human pressure (Guzmán et al. 2008). Sea turtle populations in this area suffered a great impact before 1990, recovered to some extent after that decade, reaching 1331-2166 nests per year (Zurita et al. 1993). Nevertheless, recent and quick transformation of coastal ecosystems as result of hotel infrastructure (currently 910 hotels), human settlements, harbor infrastructure and new roads are threatening the stability of these populations, which still successfully reproduce (Encalada et al. 1999; Bowen 2000; Maffucci et al. 2006; Daltabuit et al. 2007). According to the database of the conservational group Flora, Fauna, Cultura de Mexico, the number of non-nesting emergences on Kanzul beach varies from a minimum of 93 (2009) to maximum of 237 (2010) for C. mydas (average of 166.1 in the last 10 years), and from 16 (2004) to 49 (2010) for C. caretta (average of 31.9 in the last 10 years). It is uncertain if these non-nesting emergences were caused by anthropogenic direct factors, or if they were caused by false crawl, which has been reported for both species depending on turtle biology or physical conditions of sand and beach (Azanza-Ricardo et al. 2015). In any case, Kanzul beach is suffering from increasing human pressure, and therefore, detailed studies must be conducted to identify the magnitude of the threats so that conservational management programs can be designed.

\section{Materials and methods}

\section{Area of study}

The study was conducted in Kanzul camp $\left(20^{\circ} 9^{\prime} 38.67^{\prime \prime} \mathrm{N}\right.$, $87^{\circ} 27^{\prime} 2.45^{\prime \prime} \mathrm{O}$ ) in a $5.2 \mathrm{~km}$ length beach (Fig. 1). Kanzul is one of the most important loggerhead turtle nesting beach in the western Atlantic (Cliffton et al. 1981; Zurita et al. 1993), with an average nesting number of 276 per year (1379 nest: 2010-2014; FFCM 2010, 2011, 2012, 2013, 2014). It is also a relevant green turtle nesting area, with an average nesting number of 1205 per year (6027 nest: 2010-2014; FFCM 2010, 2011, 2012, 2013, 2014). In addition, the Quintana Roo loggerhead populations have shown high genetic diversity compared with other Atlantic populations (Encalada et al. 1999). Therefore, Kanzul beach is protected by the Mexican General Law of Ecological Equilibrium and Environmental Protection (DOF 2000), and the Mexican General Wildlife Law (DOF 2013, 2014).

\section{Methods}

The nesting selection of loggerhead and green turtle was studied in 11 zones of $500 \mathrm{~m}$ each (except the first and last zones with lengths of $250 \mathrm{~m}$ and $200 \mathrm{~m}$, respectively). These zones were differentiated by markers flags during the study. One row of houses and buildings separate the inner road from the beach. Field work started with the nesting season in May 2014 until the end of the season (October 2014). Nest number of each species was recorded, and the non-nesting emergences when were detected. Data was collected by the authors with help of volunteers who participated in the 2014 turtle conservation season of the Flora, Fauna and Culture of Mexico ONG. Day and night patrols were performed every day, and number of volunteers varied according to the months (2-7 people). Nesting selection and impact of nine anthropogenic threats was conducted according to Fig. 2.

The results of this study show three threats as high impact level; artificial beachfront lighting that potentially can mislead hatchlings or females (AL), beach furniture that block the movement of hatchlings or females (BF), and direct pressure by tourist presence (PT). For these three threats, a range with five categories (extreme, high, moderate, low and not harmful) was created. This range allowed us to detect the highest total impact in each area to implement priority actions. A value 
Fig. 1 Map showing the studied area, located in the Kanzul beach in the state of Quintana Roo (gray), in the Yucatan Peninsula (Mexico). The square indicates the $5.2 \mathrm{~km}$ length of the area of study

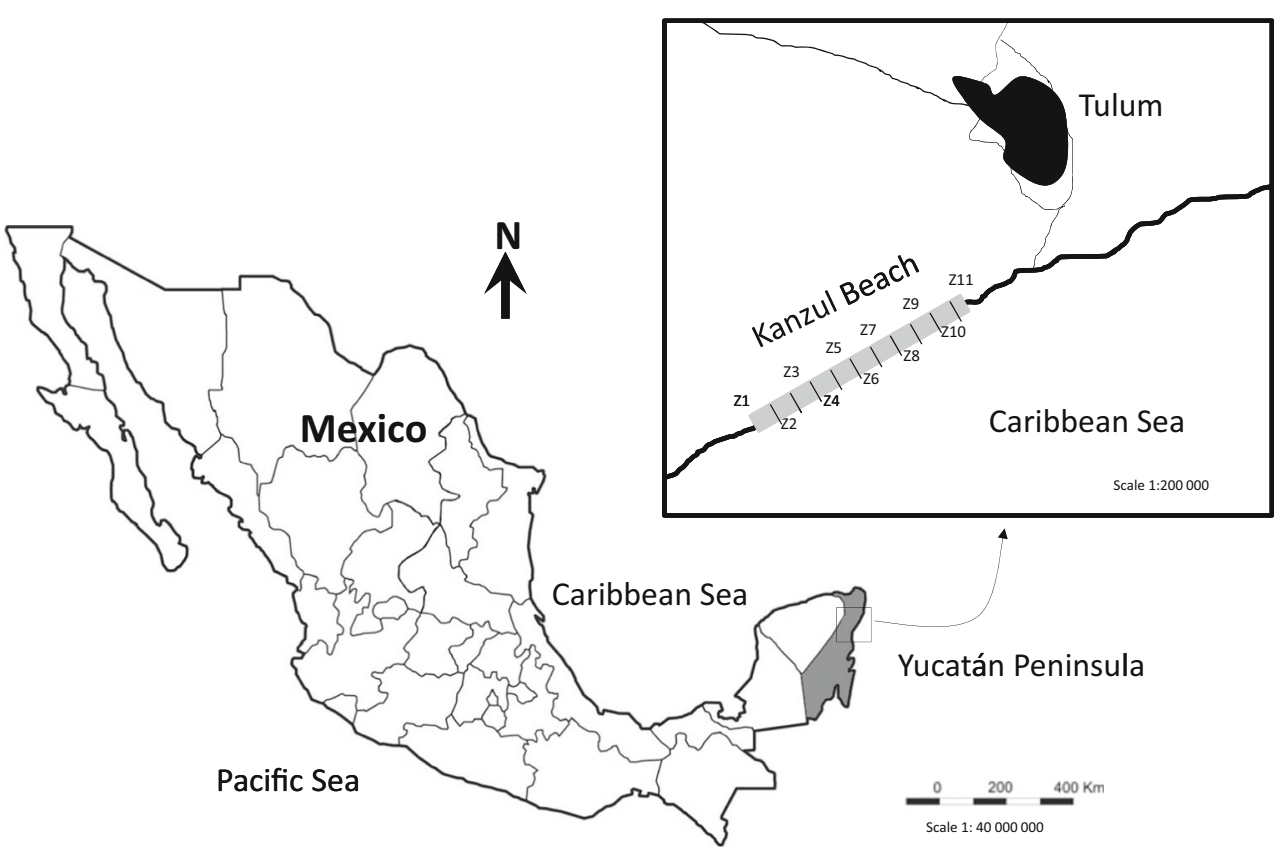

from 0 to 4 was determined, where 0 is harmless and 4 is extremely harmful at each category. For the determination of the amount of AL we considered the parameters of Table 1. This classification is based on physiological studies of: spectral sensitivity (Granda and O'shea 1972), light offspring orientation (Witherington 1992), and light sources and intensities (Witherington and Bjorndal 1991; Ferreira et al. 1992). No references were found for the estimation of the BF magnitude. Therefore, we designed a classification in order to establish five threat categories (Table 1). Magnitude of disturbance by PT was measured according to the ranges of Table 1. Even though the number of rooms in private houses is not known, occupancy is occasional and very uncommon; therefore, these buildings were not taken into account as a factor of pressure and thus were coded as 0 rooms.

Nests were recorded after hatchings leave the nest, broken and no broken eggs were counted in order to detect hatching success, using the Miller (1999) method.

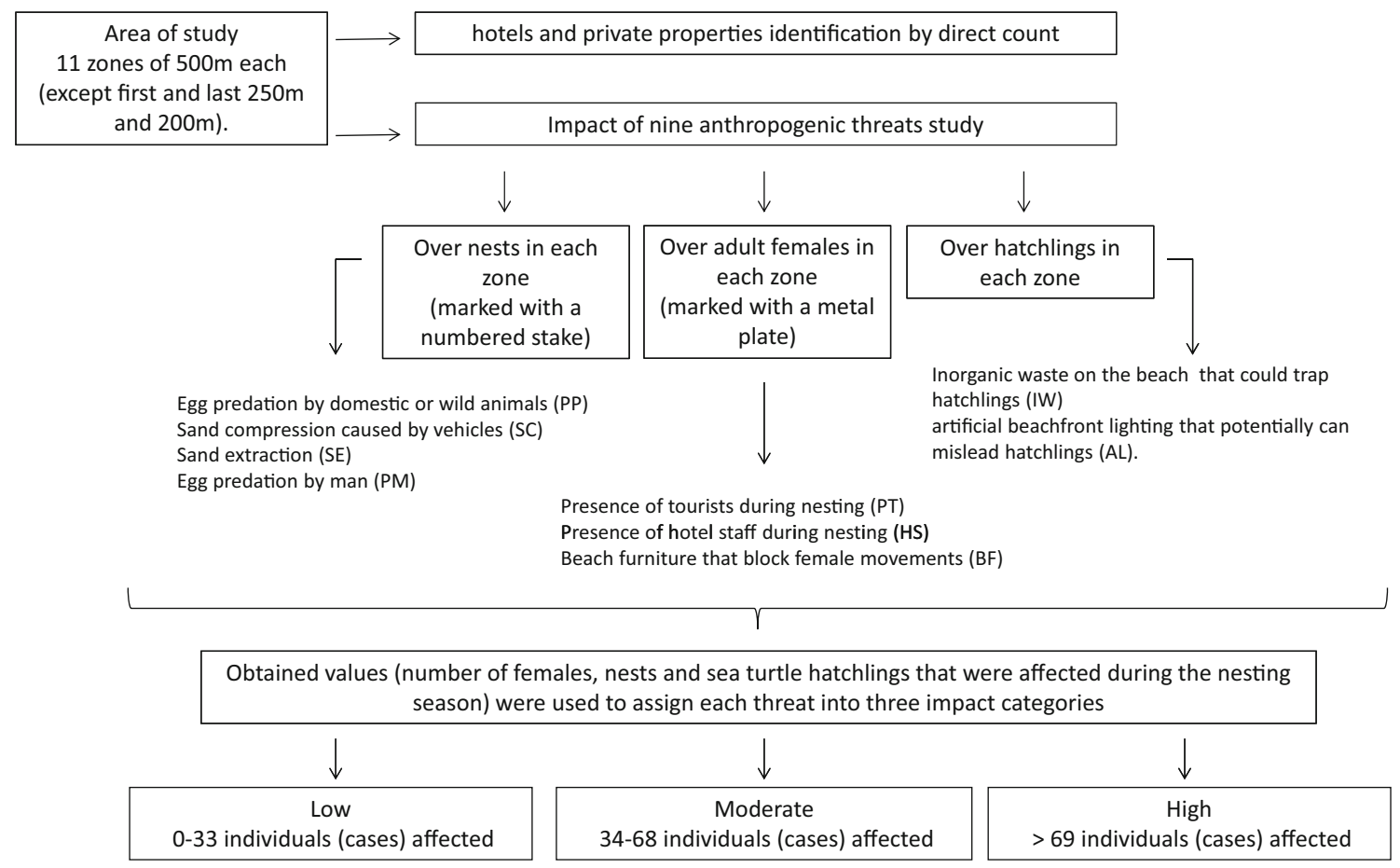

Fig. 2 Flow diagram methodology for nesting selection and impact determination of nine anthropogenic threats 
Table 1 Category and index value used to determine the magnitude of each one of the three highest threats detected. Artificial beachfront lighting that can potentially mislead hatchlings or females (AL), presence of beach furniture that block hatchling or females movements (BF), and presence of tourists (number rooms of hotels and private properties) (PT)

\begin{tabular}{|c|c|c|c|c|}
\hline Category & Index value & $\mathrm{AL}$ & $\mathrm{BF}$ & PT \\
\hline Extreme & 4 & $\begin{array}{l}\text { White lighting. Fluorescent lighting. } \\
\text { Dyed incandescent lighting (blue and green). } \\
\text { White flashlight. }\end{array}$ & Do not remove the furniture. & $31-40$ \\
\hline High & 3 & High pressure sodium vapor lighting. & Pile furniture without removal from the beach. & $21-30$ \\
\hline Moderate & 2 & $\begin{array}{l}\text { Open fires. Yellow phosphorus Lighting Lamps } \\
\text { with filter Large Combi or orange. } \\
\text { Incandescent lighting (yellow and red). }\end{array}$ & Pile furniture in the upper part of the beach. & $11-20$ \\
\hline Low & 1 & $\begin{array}{l}\text { Low pressure sodium vapor lighting. LED. } \\
\text { Neon tubes. }\end{array}$ & Withdrawing easily movable furniture. & $1-10$ \\
\hline Not harmful & 0 & No lights or turn off completely. & No furniture. & 0 \\
\hline
\end{tabular}

A $f$ Cohen variable association test (Solanas et al. 2004) was used to analyze the possible association of i) Nesting selection and ii) Hatching success with threatened zones. For other possible interactions between variables, parametric and non-parametric correlation tests were used after assessing the normality of the data (Shapiro-Wilk test) using the PAST software (Hammer et al. 2001).

\section{Results}

In this study 88 buildings and 818 rooms were found. These buildings included private houses and small hotels (Table S1). High number of buildings were found in zones 5 and 6 (13 and 12 buildings, respectively), and a high number of rooms were detected in zones 8, 9 and 3. In zones 11 and 1, only one building in each zone was found. Zone 1 had the lowest number of rooms, with a total of eight (Table S1). Despite the presence of these buildings, 1425 nests (369 loggerhead and 1056 green turtle nests) were detected. Nevertheless, 309 turtles emerged and abandoned nesting (61 loggerheads and 248 green turtles). These non-nesting emergences were, in many cases, with direct pressure of tourist, but we also reported cases of non-nesting emergences in areas with low anthropogenic pressures without human presence.

Our results showed that $14.19 \%$ of all nesting attempts suffered some anthropogenic threats during the nesting period, of which $41.06 \%$ were caused by BF. $34.15 \%$ of nesting withdraw were occasioned by PT. In contrast, anthropogenic threats detected during incubation period account to only $0.77 \%$ and during hatching to $4.7 \%$, of which, $94.03 \%$ was due to $\mathrm{AL}$.

Among all of the anthropogenic factors studied, three impacts were identified as high: PT, AL, and BF (Table 2). The magnitude of these three highest threats (AL, BF, PT) in high and low season are shown in Table S1.

Nesting preference areas were detected; loggerhead had preference for zones 4, 6 and 9 and zones 3, 6 and 9 in high and low seasons, respectively (Fig. 3). Zones 8, 4 and 1 showed the lowest nesting number in both seasons. Green turtle showed preference for zones 1,2 and 4, and less preference for zone 8 and 11 in both high and low seasons (Fig. 3). A high correlation of green turtle nesting selection in high and low seasons was detected (Spearman, $r=0.86 ; p<0.005$ ), but no correlation of both seasons in loggerhead (Spearman, $r=0.06: p>0.05$ ) was found. It was also found that loggerhead prefers less impacted areas for nesting in low season $(f=0.71)$. Nevertheless, we did not find that association in high season. Green turtle has selected less impacted area for nesting in both seasons, but statistical association between variables was relatively low $(f=0.49$ High Season and $f=0.33$ Low Season).

Hatching success was higher in zone 1 and 6 for loggerhead and green turtle, respectively (Fig. 4). Lowest values of hatching success were detected in zone 8 for both species. An association between loggerhead hatching success and total impact was found $(f=0.66$ High Season; $f=0.71$ Low Season). Green turtle hatching success was lower in high impacted areas, nevertheless statistical association between variables was relatively low $(f=0.33$ High Season and $f=0.48$ Low Season).

\section{Discussion}

A high number of buildings (88) and rooms (818) were found in the studied area, indicating an average density of 16.6 buildings per kilometer. This shows a great impact on the beach line, which impedes reaching the beach line from inland, and therefore blocks the natural connection of animals between the forest and the beach, resulting in habitat fragmentation. The estimated Kanzul building density is higher than other Mexican touristic areas such as Cancún $(8.2$ hotels/Km), or other massive impacted areas in the world such as Sal island in Cape Verde (4.3 hotels/Km), and Varadero in Cuba (2.5 hotels/Km) (Artiles-Viera 2013). Nevertheless, Kanzul room 
Table 2 Number of loggerhead and green turtles individuals affected by the nine studied impacts in different terrestrial life phases. PT: Disturbed by the presence of tourists, HS: disturbance by hotel staff, PP: animal disturbance and predation of eggs, AL: artificial beachfront lighting that potentially can mislead hatchlings or females, BF: presence of beach furniture that block the movement of hatchlings or females, IW: presence of inorganic waste on the beach as plastic, glass, cans or rubbish that trap hatchlings, SC: sand compression caused by vehicles, SE: sand extraction, PM: egg predation by man

\begin{tabular}{llllllllll}
\hline & PT & HS & PP & AL & BF & IW & SC & SE & PM \\
\hline NESTING & 84 & 48 & 2 & 11 & 101 & 0 & 0 & 0 & 0 \\
INCUBATION & 3 & 0 & 5 & 0 & 0 & 0 & 0 & 0 & 3 \\
HATCHING & 1 & 0 & 0 & 63 & 0 & 3 & 0 & 0 & 0 \\
TOTAL & 88 & 48 & 7 & 74 & 101 & 3 & 0 & 0 \\
IMPACT CATEGORY & High & Mod. & Low & High & High & Low & Low & Low \\
\hline
\end{tabular}

density is lower $(157.3 \mathrm{rooms} / \mathrm{Km})$, and therefore, the total impact is significant lower than crowded areas as Cancún $(1591.8 \mathrm{rooms} / \mathrm{Km})$ and Varadero $(750 \mathrm{rooms} / \mathrm{Km})$ (ArtilesViera 2013). The number of tourists in our study area is still unknown. Nevertheless, the nearly adjacent archeological area of Tulum receives more than 1 million of visitants per year (Ruiz et al. 2013). Thus, number of visitants of Kanzul might be similar or even higher than other eco-touristic areas of turtle nesting such as Tortugero (Costa Rica), which accounted for an elevated number of visitors per year (117817 persons in 2011) (González-Prieto and Harrison 2012).

Buildings and room density in our study area are not equally distributed along the beach. Zones 5 and 6 accounted for 13 and 12 buildings, respectively, but zones 8,9 and 3 have larger capacity hotels and therefore present higher numbers of rooms, which result in greater anthropogenic impact in those zones. As expected, the highest room density, and therefore high impacted areas, are located in zones 8, 9 and $3(126,116$ and 85 rooms/per zone, respectively), which account for $40 \%$ of total occupancy of the area in high season. These elevated densities do not match completely with the idea of ecotourism, defined as an "economic activity result of traveling to a high quality natural conserved area, maintained undisturbed by human activity and uncontaminated, which sustains the wellbeing of the local people, and involves interpretation and education" (Jacobson and Robles 1992). Nonetheless, the importance of tourism for the Tulum local development is indisputable; therefore, conservation goal of areas with elevated presence of tourists depends strictly on the appropriated management. Accordingly, we suggest some strategies to be carried out in the Kanzul beach across this paper.

Despite the high number (1425) of nests detected, a significant number of turtles (61 loggerheads and 248 green turtles) did not spawn. These non-nesting emergences might be consequence of a false crawl, defined by Miller (1997) as the cases of turtles that emerge from the water but do not deposit a clutch, as a result of combination of several factors that includes turtle biology characteristics, nest density, or weather conditions (Miller 1997; Azanza-Ricardo et al. 2015). Nevertheless, taking into account that i) the fidelity of marine turtles to the first
Fig. 3 Nesting selection of loggerhead and green turtle in high and low seasons in Kanzul Beach (Mexico)

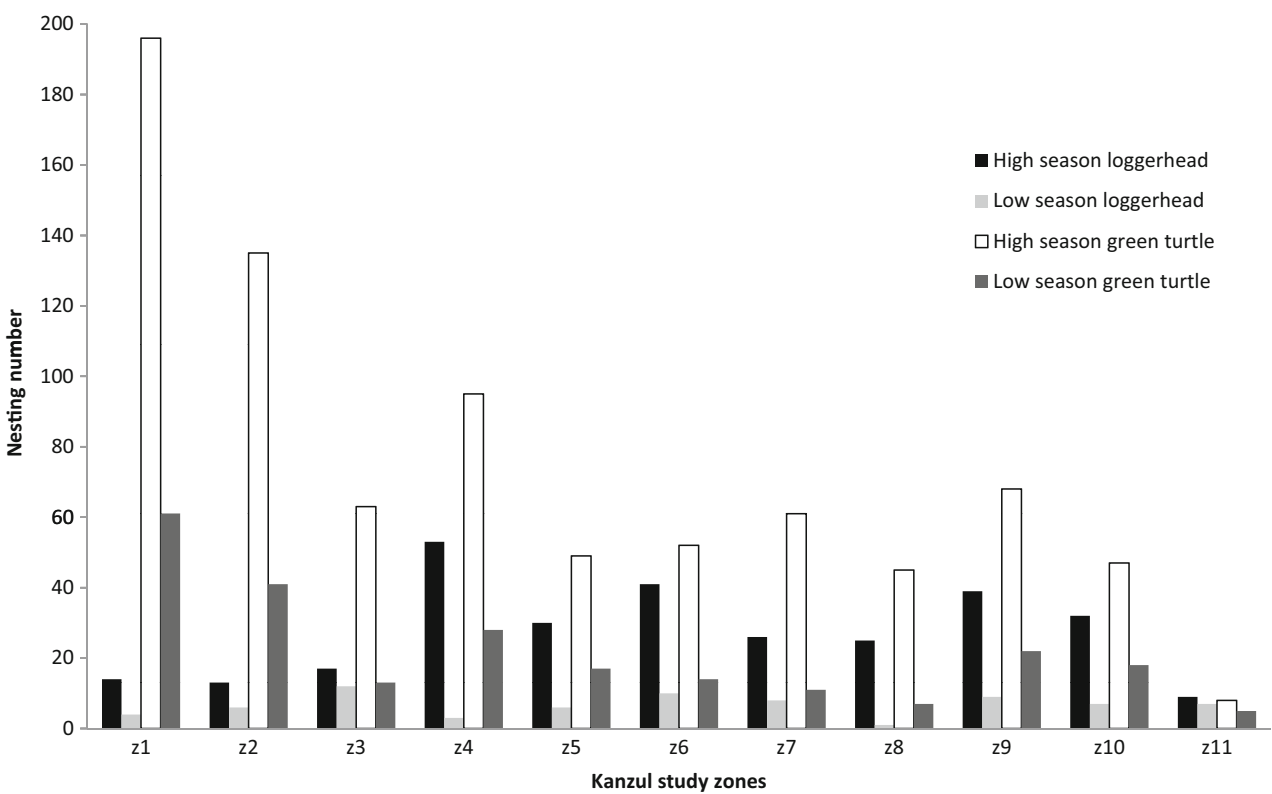




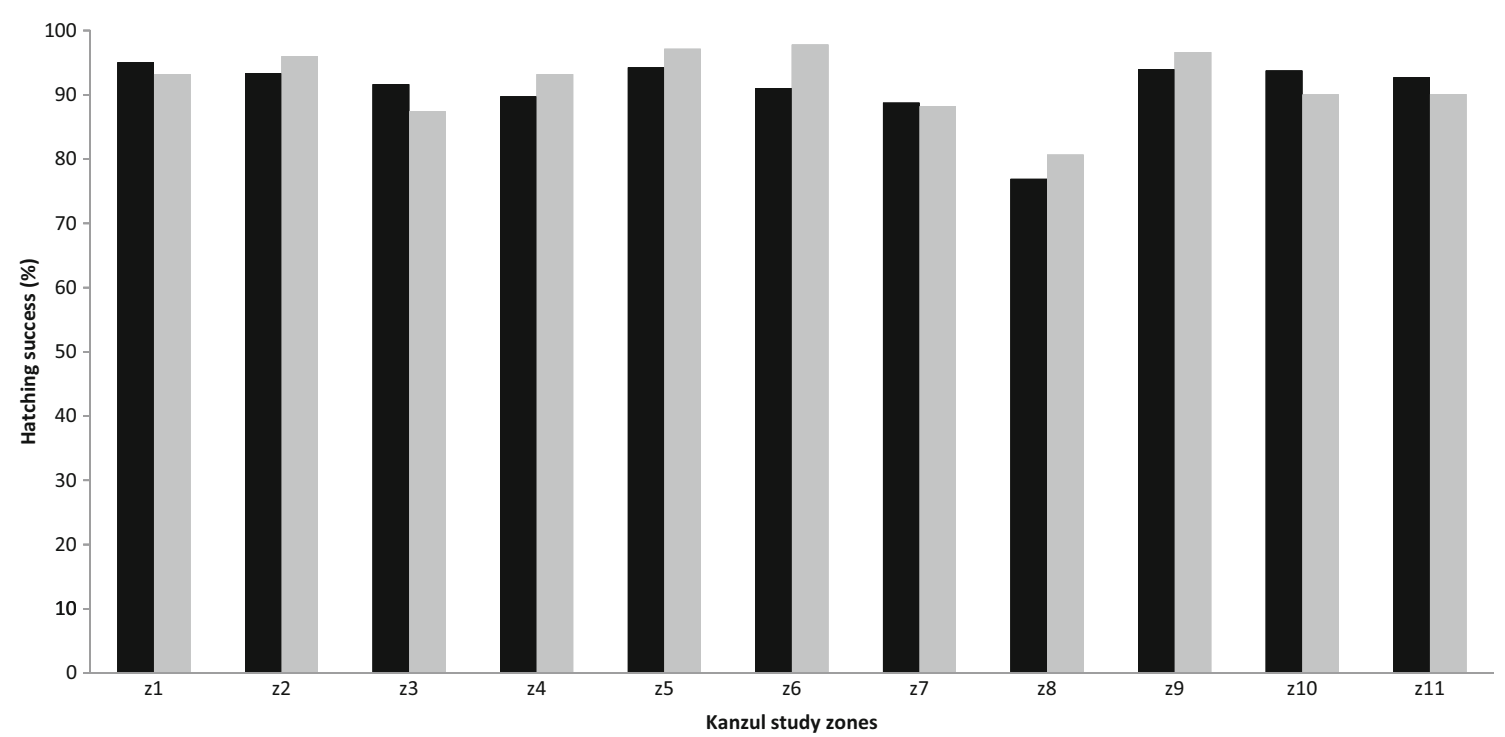

Fig. 4 Hatching success of loggerhead (black) and green turtle (gray) in Kanzul Beach (Mexico)

nesting beach is very high $(97.2 \%$ of green turtles back to the first nesting beach; Ferrer et al. 2007) and that ii) several cases of non-nesting emergences in Kanzul occurred with tourist near the females or the nests, we would suggest that the majority of the 309 non-nesting emergence cases reported in the 2014 season, could be a consequence of anthropogenic pressures (high tourist density in the beach and/or noisy anthropogenic activity). But not all cases may have been caused by human impact; some non-nesting emergences occurred in absence of human presence (false crawl). This might be related to physiological events such as egg shell production, or it might be linked to sand/beach characteristics such as moisture (Miller 1997). Detailed field work and monitoring must be conducted to determine the exact proportion of false crawl and nest abandonment as a consequence of human activity.

Threats were more intensive in nesting selection period $(14.19 \%)$ and hatching $(4.7 \%)$ than in incubation period $(0.77 \%)$, in accordance with the higher vulnerability of these periods reported in other studies (Witherington 1992; Witherington and Martin 1996). PT and AL were detected as main threats during nesting selection and hatching. Nevertheless, nesting success rate in Kanzul (78.31\%) was similar to other important protected areas such as Tortuguero (Costa Rica) (80.4\%; Atkinson et al. 2011). Those values were higher to other important areas such as Dalaman-Sarigerme (Turkey), Göksu delta (Turkey) and Boa Vista (Cape Verde) with nesting success rates of $24.6 \%, 22.9 \%$ and $33.0 \%$, respectively (Kaska et al. 2010; Durmuş et al. 2011; Sousa et al. 2012).

Nine anthropogenic factors were studied and reported as major threats to marine turtle species (Witherington and Martin 1996; Witherington 2000; Ceballos-Fonseca 2004; Chacón-Chaverri et al. 2008; Atkinson et al. 2011; González-Prieto and Harrison 2012). Our results in Kanzul showed that three of the nine factors were classified in the category of high impact: nesting disturbed by the presence of tourists (PT), artificial beachfront lighting that potentially can mislead hatchlings or females (AL) and presence of beach furniture that block the movement of hatchlings or females (BF). BF was detected only at the stage of nesting and showed the highest impact $(41.06 \%)$, agreeing with the study of Witherington (2000) which identifies waste (glass, metals, plastics and styrofoam), beach equipment and other obstacles that entangle or impede the passage of nesting turtles and their offspring as major threats. Although Kanzul Beach is regulated by law (DOF 2013), and that all furniture must be removed every afternoon, some hotels do not follow these directions. Therefore, we recommend three strategies: i) Remind to all hotels the importance to remove furniture from the beach; ii) Create an eco-touristic certificate denominated "Friendly Marine Turtle Hotel", which will certify the good conservational practices of hotels; and iii) Increase vigilance from the police department.

On the other hand, PT was responsible for the $34.15 \%$ of the abandoned nesting in our study area. This agrees with the idea that sea turtles are mainly disturbed by the presence of people during nesting (Carr and Giovannoli 1957; Carr and Ogren 1959; Witherington and Martin 1996). Witherington and Martin (1996) found that the presence of people moving within the turtle vision area may cause nesting abandonment. Similar results were reported by other authors (Carr and Giovannoli 1957; Carr and Ogren 1959). Tourism is very important for the economy of the area, therefore, two strategies are recommended: i) Hotels must perform a short explanation to every guest to avoid direct pressure during nesting and emphasize the prohibition by Mexican law to touch, light, speak loud or get close to any marine turtle; and ii) Create a "Beach Turtle Guide"; a person that can provide advice to tourists on how to behave on the beach during nesting and 
hatching periods, and guide tourists in a proper manner to observe nesting, adults and offspring. This work must be performed especially in hotels that represent higher impact, especially in zones 8 and 4, which showed the strongest pressure (Table S1). This idea has been developed in other important marine turtle nesting areas such as Costa Rica's Tortuguero National Park, where it has helped to mitigate negative tourism impacts and provided local economic benefits (Jacobson and Robles 1992). In conclusion, the "Friendly Marine Turtle Hotel" certificate will incentive hotel managements to implement policies and procedures that will promote the education and appropriate behavior of tourists, including participation in the "Beach Turtle Guide" program and helping remove furniture from the beach every day.

Although relatively low pressure is detected during hatching (4.7\%), $94.03 \%$ of this figure is due to AL. Similar results were obtained by other authors, where neonates moved toward bright artificial lights (Mrosovsky and Shettleworth 1968; Kamrowski et al. 2014). Therefore, artificial lighting intensity can disorient hatchlings away from the sea and leave them vulnerable to dehydration, exhaustion and depredation (Witherington and Martin 1996; Kamrowski et al. 2014). As a result, bright artificial lighting visible from the nesting beach can cause high mortality in the offspring (Mazor et al. 2013; Davies et al. 2014). Law DOF 2013 sets that the luminous flux must be directed down and away from the beach, and the following should be used: i) Screens or turn signals, ii) Low voltage spotlights $(40 \mathrm{~W})$, iii) Sources of light yellow or red. However, we realize that these laws are not achieved on Kanzul beach; therefore, we recommend the implementation of public and private installations and higher control by the authorities.

Finally, our study detected that nesting selection is affected by human pressures; zone 8 was classified as very harmful and in concordance is the least preferred area for loggerhead and Green turtle (Fig. 3; Table S1). We also found an association of nesting selection with low impacted areas in low season for C. caretta $(f=0.71)$, which indicates that loggerhead prefer to nest in areas of less human pressure. Nonetheless, that correlation was relatively low in both seasons for $C$. mydas $(f=0.49$ High Season and $f=0.33$ Low Season), although this species has selected the less impacted area for nesting in both seasons. Several studies have detected that hatching success is higher in natural beaches than in human impacted beaches (Pike 2008; Kaska et al. 2010; Bevan et al. 2014). Accordingly, areas with higher impact produce lower values of hatching success. We have obtained the lower percentage of success in zone 8 for both species (Fig. 4), and found an association between hatching success of $C$. caretta and low impact ( $f=0.66$ High Season; $f=0.71$ Low Season), corroborating this idea. This pattern was corroborated with green turtle, where hatching success was lower in high impacted areas, nevertheless statistical association between variables was relatively low ( $f=0.33$ High Season and $f=0.48$ Low Season).
In conclusion, our results show that anthropogenic threats caused by tourism and urban development are producing nesting habitat loss, endangering not only the two studied species but all marine turtles of the area. Nevertheless, quick remediation may achieve the protection of critical stages of these two marine turtle species and the development of a proper eco-touristic area. Evaluation of these threats is essential to prioritize management actions to preserve these species.

Acknowledgements We want to thank to Flora, Fauna and Culture of Mexico conservation group, for its efforts protecting sea turtles, for making this research possible, and to the employees and volunteers who participated in the 2014 nesting season that helped with the field sampling. We want to thank to two anonymous referees for his/her careful revision of our manuscript. We also want to thank to Robert Pérez and Maria Teresa Albarracín for linguistic assistance. This work has been partially supported by the Flora, Fauna y Cultura de Mexico A.C. and the Spanish Aragón Government and European Social Fund co-funding support to the Bioflora research group.

\section{References}

Arellano-Peralta VA, Medrano-Gonzalez L (2015) Ecology, conservation and human history of marine mammals in the Gulf of California and Pacific coast of Baja California, Mexico. Ocean Coast Manag 104:90-105

Artiles-Viera M (2013) EL sector del turismo en Cabo Verde. In: Informe técnico Proexca. Gobierno de Canarias, España

Atkinson C, Nolasco del Aguila D, Harrison E (2011) Reporte del programa de tortuga verde 2010. Marisla Foundation, Tortuguero

Azanza-Ricardo J, Gerhartz-Muro JL, Martin-Viana YF, MoncadaGavilan F (2015) Effectiveness of monitoring techniques employed to determine reproductive success of marine turtles in Cuba. Latin Amer J Aquat Res 43:548-556

Bevan E, Wibbels T, Najera BMZ, Martínez MAC, Martínez LAS, Reyes DJL, Hernández MH, Gamez DG, Pena LJ, Burchfield PM (2014) In situ nest and hatchling survival at rancho nuevo, the primary nesting beach of the kemp's ridley sea turtle, Lepidochelys kempii. Herpetol Conserv Biol 9:563-577

Bolongaro A, Márquez AZ, Torres Rodríguez V, García A (2010) Vulnerabilidad de sitios de anidación de tortugas marinas por efectos de erosión costera en el estado de Campeche. Universidad Autónoma de Campeche, Mexico

Bowen BW (2000) What is a loggerhead turtle? The genetic perspective. In: Loggerhead Sea turtles. Smithsonian Institution, Washington

Carr A, Giovannoli L (1957) The ecology and migrations of sea turtles. Results of field work in Costa Rica, 1955. Am Mus Novit 1835:1-32

Carr A, Ogren L (1959) The ecology and migrations of sea turtles. Dermochelys in Costa Rica. Am Mus Novit 1958:1-29

Ceballos-Fonseca C (2004) Distribución de las playas de anidación y aéreas de alimentación de tortugas marinas y sus amenazas en el Caribe colombiano. Boletín de Investigaciones Marinas y Costeras 33:79-99

Chacón-Chaverri D, Eckert KL (2007) Leatherback Sea turtle nesting at Gandoca Beach in Caribbean Costa Rica: management recommendations from fifteen years of conservation. Chelonian Conserv Biol 6:101-110

Chacón-Chaverri D, Dick B, Harrison E, Sarti L, Solano M (2008) Manual sobre técnicas de manejo y conservación de las tortugas marinas en playas de anidación de Centroamérica. Secretaría Pro 
Tempore de la Convención Interamericana para la Protección y Conservación de las Tortugas Marinas (CIT), San José, Costa Rica

Chaloupka M (2003) Stochastic simulation modeling of loggerhead sea turtle population dynamics given exposure to competing mortality risks in the western South Pacific. In: Bolten $\mathrm{AB}$, Witherington $\mathrm{BE}$ (eds) Loggerhead Sea turtles. Smithsonian Books press, Washington, pp. 274-294

Chaloupka MY, Limpus CJ (2005) Estimates of sex and age-classspecific probabilities for a southern great barrier reef green turtle population. Mar Biol 146:1251-1261

Chaloupka M, Parker D, Balazs G (2004) Modeling post-release mortality of pelagic loggerhead sea turtles exposed to the Hawaii-based pelagic longline fishery. Mar Ecol Prog Ser 280:285-293

Cliffton K, Cornejo DO, Felger RS (1981) Sea turtles of the Pacific coast of México. In: Bjorndal KA (ed) Biology and conservation of sea turtles. Smithsonian Institution Press, Washington, pp. 199-209

Costello MJ (2015) Biodiversity: the known, unknown, and rates of extinction. Curr Biol 25:368-371

D.O.F. (2000) Reglamento de la Ley General del Equilibrio Ecológico y la Protección al Ambiente en materia de Impacto Ambiental. Estados Unidos Mexicanos. DOF 30 de mayo de 2000

D.O.F. (2013) Establece las especificaciones para la protección, recuperación y manejo de las poblaciones de las tortugas marinas en su hábitat de anidación. DOF 1 de febrero de 2013

D.O.F. (2014) Reglamento de la Ley General de Vida Silvestre. Estados Unidos de México. Última reforma DOF 20 de abril de 2014

Daltabuit M, Cisneros H, Valenzuela E (2007) Globalización y sustentabilidad. El turismo en el sur de Quintana Roo. Universidad Nacional Autónoma de México, México

Davies TW, Duffy JP, Bennie J, Gaston KJ (2014) The nature, extent, and ecological implications of marine light pollution. Front Ecol Environ 12:347-355

Durmuş SH, Ilgaz C, Özdemir A, Yerli SV (2011) Nesting activity of loggerhead turtles (Caretta caretta) at Göksu Delta, Turkey during 2004 and 2008 nesting seasons. Ecol Balkanica 3:95-106

Encalada SE, Zurita JC, Bowen BW (1999) Consecuencia genética del desarrollo costero: Las colonias de tortugas marinas en X'cacel, México. Noticiero de Tortugas Marinas 83:8-10

Ferreira SN, Filho GCM, Patiri VJ (1992) The influence of artificial lighting on the reproduction of sea turtles. Unpublished report from the Eleventh National Seminar of Electrical Power Distribution, Bahia, Brazil. 20 p

Ferrer Y, DÍaz-Fernández R, Díaz R (2007) Características de la anidación de la tortuga verde Chelonia mydas (Testudinata, Cheloniidae) en la playa Caleta de los Piojos, Cuba, a partir de marcaciones externas. Anim Biodivers Conserv 30:211-218

FFCM Flora, Fauna y Cultura de México (2010) Programa de protección y conservación de tortugas marinas en el litoral central del estado de Quintana Roo: Informe final, Temporada 2010. Flora, Fauna y Cultura de México, AC. 44 pp

FFCM Flora, Fauna y Cultura de México (2011) Programa de protección y conservación de tortugas marinas en el litoral central del estado de Quintana Roo: Informe final, Temporada 2011. Flora, Fauna y Cultura de México, AC. 46 pp

FFCM Flora, Fauna y Cultura de México (2012) Programa de protección y conservación de tortugas marinas en el litoral central del estado de Quintana Roo: Informe final, Temporada 2012. Flora, Fauna y Cultura de México, AC. 45 pp

FFCM Flora, Fauna y Cultura de México (2013) Programa de protección y conservación de tortugas marinas en el litoral central del estado de Quintana Roo: Informe final, Temporada 2013. Flora, Fauna y Cultura de México, AC. 43 pp

FFCM Flora, Fauna y Cultura de México (2014) Programa de protección y conservación de tortugas marinas en el litoral central del estado de Quintana Roo: Informe final, Temporada 2014. Flora, Fauna y Cultura de México, AC. 46 pp
Frazier JG (2000) Conservación Basada en la Comunidad. Técnicas de Investigación y Manejo para la Conservación de las Tortugas Marinas. UICN/CSE Grupo Especialista en Tortugas Marinas No4

Gardner S, Nichols W (2001) Assessment of sea turtle mortality rates in the Bahia Magdalena, Baja California Sur, Mexico. Chelonian Conserv Biol 4:197-199

González-Prieto C, Harrison E (2012) Reporte del programa de tortuga verde 2011, en Tortuguero, Costa Rica. Sea Turtle Conservancy y Ministerior de Energia. Ambiente y Telecomunicaciones, Costa Rica

Granda AM, O'shea PJ (1972) Spectral sensitivity of the green turtle (Chelonia mydas) determined by electrical responses to heterochromatic light. Brain Behav Evol 5:143-154

Guzmán HV, Nolasco SJ, García AP (2008) Informe técnico final 2007. Programa de conservación de tortugas marinas en Laguna de Términos, Campeche, México

Hamann M, Godfrey MH, Seminoff JA, Arthur KE, Barata PCR, Bjorndal KA, Bolten AB, Broderick AC, Campbell LM, Carreras $C$ et al (2010) Global research priorities for sea turtles: informing management and conservation in the twenty-first century. Endanger Species Res 11:245-269

Hammer Ø, Harper DAT, Ryan PD (2001) PAST: paleontological statistics software package for education and data analysis. Palaeontol Electron 4:1-9

Jackson JBC, Kirby MX, Berger WH, Bjorndahl KA, Botsford LW, Bourque BJ, Bradbury RH, Cooke R, Erlandson J et al (2001) Historical overfishing and the recent collapse of coastal ecosystems. Science 293:629-638

Jacobson SK, Robles R (1992) Ecotourism, sustainable development, and conservation education: development of a tour guide training program in Tortuguero, Costa Rica. Environ Manag 16:701-713

Julian F, Beeson M (1998) Estimates of marine mammal, turtle, and seabird mortality for two California gillnet fisheries: 1990-1995. Fish B-NOAA 96:271-284

Kamezaki N, Matsui M (1997) A review of biological studies on sea turtles in Japan. Jpn J Herpetol 17:16-32

Kamezaki N, Matsuzawa Y, Abe O, Asakawa H, Fujii T, Goto K, Hagino S, Hayami M, Ishii M, Iwamoto T et al (2003) Loggerhead turtle nesting in Japan. In: Bolten AB, Witherington BE (eds) Loggerhead Sea turtles. Smithsonian Books Press, Washington D.C, pp. 210-217

Kamrowski RL, Limpus C, Moloney J, Hamann M (2012) Coastal light pollution and marine turtles: assessing the magnitude of the problem. Endanger Species Res 19:85-98

Kamrowski RL, Limpus C, Jones R, Anderson S, Hamann M (2014) Temporal changes in artificial light exposure of marine turtle nesting areas. Glob Chang Biol 20:2437-2449

Kaska Y, Baskale E, Urhan R, Katilmis Y, Gidis M, Sari F, Sozbilen D, Canbolat AF, Yilmaz F, Barlas M et al (2010) Natural and anthropogenic factors affecting the nest-site selection of loggerhead turtles, Caretta caretta, on Dalaman-Sarigerme beach in south-West Turkey. Zool Middle East 50:47-58

Maffucci F, Kooistra WHCF, Bentivegna F (2006) Natal origin of loggerhead turtles, Caretta caretta in the neritic habitat of the Italian coasts, Central Mediterranean. Biol Conserv 127:183-189

Mazor T, Nc L, Possingham HP, Levy Y, Rocchini DE, Richardson AJ, Kark S (2013) Can satellite-based night lights be used for conservation? The case of nesting sea turtles in the Mediterranean. Biol Conserv 159:63-72

Miller J (1997) Reproduction in sea turtles. In: Lutz PL, Musick JA (eds) The biology of SeaTurtles. CRC Marine Science Series, Boca Raton, pp. 51-81

Miller J (1999) Determining clutch size and hatching success. In: Eckert KL, Bjorndal KA, Abreu-Grobois FA, Donnelly M (eds) Research and management techniques for the conservation of sea turtles. Publication No. 4, IUCN/SSC Marine Turtle Specialist Group, Blanchard, pp 124-129 
Mrosovsky N, Shettleworth SJ (1968) Wavelength preferences and brightness cues in the water-finding behavior of sea turtles. Behavior 32:211-257

Peckham SH, Diaz DM, Walli A, Ruiz G, Crowder LB, Nichols WJ (2007) Small scale fisheries by catch jeopardizes endangered loggerhead turtles. PLoS One 2:e1041

Pike AD (2008) Natural beaches confer fitness benefits to nesting marine turtles. Biol Lett 4:704-706

Poiner IR, Harris ANM (1996) Incidental capture, direct mortality and delayed mortality of sea turtles in Australia's northern prawn fishery. Mar Biol 125:813-825

Ruiz C, González CMJ, Sánchez JS, Peña FM, Mena O, Gómez HM, López R, Borge R, Fernández LL, Coral EE, Campos BL (2013) Agendas de competitividad de los destinos turísticos de México 2013. Estudio de Competitividad Turística del destino Riviera Maya. Universidad de Quintana Roo, México

Sarti L, Barragán AR, García D, García N, Huerta P, Vargas F (2007) Conservation and biology of the leatherback turtle in the Mexican Pacific. Conserv Biol 6:70-78

Scherer-Lorenzen M (2014) The functional role of biodiversity in the context of global change. In: Coomes DA, Burslem DFRP, Simonson WD (eds) Forests and global change. Cambridge University Press Cambridge, pp 195-237

Schlacher TA, Dugan J, Schoeman DS, Lastra M, Jones A, Scapini F, McLachlan A, Defeo O (2007) Sandy beaches at the brink. Divers Distrib 13:556-560

Solanas A, Salafranca L, Fauquet J, Núñez MI (2004) Estadística descriptiva en ciencias del comportamiento. International Thomson (eds), Madrid. España

Sousa MM, Álvarez I, Marco A (2012) Impacto del Cambio Climático en la Incubación de Caretta caretta en Cabo Verde: estimaciones actuales y proyecciones futuras. ACT 3:75-94

Tomillo PS, Saba VS, Piedra R, Paladino FV, Spotila JR (2008) Effects of illegal harvest of eggs on the population decline of leatherback turtles in las Baulas marine National Park, Costa Rica. Conserv Biol 22:1216-1224

UICN (2014) La Lista Roja de la UICN de Especies Amenazadas. Versión 2014.3. <http://www.iucnredlist.org >

Verheijen FJ (1985) Photopollution: artificial light optic spatial control systems fail to cope with. Incidents, causations, remedies. Exp Biol 44:1-18

Witherington BE (1992) Behavioral responses of nesting sea turtle to artificial lighting. Herpetologica 48:31-39

Witherington BE (2000) Reducción de Amenazas al Hábitat de Anidación. Técnicas de Investigación y Manejo para la Conservación de las Tortugas Marinas. UICN/CSE Grupo Especialista en Tortugas Marinas 4:204-210

Witherington BE, Bjorndal KA (1991) Influences of wavelength and intensity on hatchling sea turtle phototaxis: implications for seafinding behavior. Copeia 4:1060-1069

Witherington BE, Martin RE (1996) Understanding, assessing, and resolving light-pollution problems on sea turtle nesting beaches. In: FMRI Informe Técnico TR-2. Florida Marine Research Institute, Florida

Witherington BE, Bjorndal KA, Mccabe CM (1990) Temporal pattern of nocturnal emergence of loggerhead turtle hatchlings from natural nests. Copeia 4:1165-1168

Wyneken J, Burke TJ, Salmon M, Pederson DK (1988) Egg failure in natural and relocated sea turtle nests. J Herpetol 22:88-96

Zurita JC (2009) Situación de la tortuga caguama Caretta caretta en el Golfo de México y Caribe mexicano. Memorias de la Reunión Nacional sobre Conservación de Tortugas Marinas, Veracruz. Comisión Nacional de Áreas Naturales Protegidas, SEMARNAT, México

Zurita JC, Herrera R, Prezas B (1993) Tortugas marinas del Caribe. Biodiversidad Marina y Costera de México. Comisión Nacional de Biodiversidad y CIQRO, México 